\title{
UTICAJ TRENINGA NA OPŠTE I SPECIFIČNE MOTORIČKE SPOSOBNOSTI ODBOJKAŠICA UZRASTA 13-14 GODINA
}

\author{
Goran Nešić ${ }^{1}$, Dejan Ilić ${ }^{1}$, Nikola Majstorović ${ }^{1}$, Vladimir Grbić ${ }^{1}$ i Nedžad Osmankač ${ }^{2}$ \\ ${ }^{1}$ Fakultet sporta i fizičkog vaspitanja Univerzitet u Beogradu, Srbija \\ ${ }^{2}$ Fakultet za sport i turizam, Univerzitet Educons, Srbija
}

\section{SAŽETAK}

Fizički razvoj i usavršavanje motoričkih sposobnosti, značajne su komponente na koje se može djelovati programiranim fizičkim vježbanjem, odnosno treningom.

Cilj ove studije je prikaz i analiza uticaja odbojkaškog treninga na promjene nekih opštih i specifičnih motoričkih sposobnosti odbojkašica uzrasta 13-14 godina.

Uzorak ispitanika je predstavljalo 40 ispitanica, polaznica škole odbojke "DIF“ iz Beograda. U ovom istraživanju uzorak varijabli je podijeljen u dva subuzorka (varijable za procjenu opštih motoričkih sposobnosti i varijable za procjenu specifičnih sposobnosti u odbojci). Prvog dana, izvršena su mjerenja tjelesne visine i tjelesne mase (u trim kabinetu) i sprovedeni testovi: skok u dalj iz mjesta (SUD), dohvat u bloku (DUB), trčanje na $20 \mathrm{~m}$ (TRC), a drugog dana sprovedena su preostala tri testa (Rasel-Langov test - prsti (RLTP), Rasel-Langov test - „čekić“ (RLTC) i servis (RLTS)). Ponovljeno testiranje (re-test) je obavljen kroz tri mjeseca.

Kada se radi o eksperimentalnom faktoru koji je djelovao tokom tri mjeseca, važno je napomenuti da su se treninzi održavali 4 puta nedjeljno.

Dobijeni rezultati (primjenjena je komparativna statistika, odnosno $t$-test za male zavisne uzorke), ukazuju da je došlo do pozitivnog pomaka u svim varijablama, nakon tri mjeseca programiranog rada, a posebno je pokazana statistička značajnost varijable skok u dalj iz mjesta (SUD) i kod sve tri specifične sposobnosti (RLTP, RLTC i RLTS).

Pozitivne promjene u ispoljavanju opštih i specifičnih sposobnosti odbojkašica uzrasta 13-14 godina mogu se ostvariti isključivo kvalitetno programiranim treninzima, koje sprovode obrazovani stručnjaci.

Ključne riječi: motorne vještine, odbojkašice, efekti treninga.

\section{UVOD}

Odbojka je vrlo atraktivna, interesantna, kompleksna i dinamična sportska grana, sa brzim transferom akcija sa jedne strane terena, na drugi, u kojoj timovi nastoje da dođu do pobjede postignuvši veći broj poena, putem uspješnog napada ili nadmudrivanjem protivnika. Fizički razvoj i usavršavanje motoričkih sposobnosti, značajne su komponente na koje se može djelovati programiranim fizičkim vežbanjem, odnosno treningom (Bompa, 2005). Tehničko-taktički zahtjevi u velikom broju sportskih disciplina uključuju česte promjene pravca u frontalnoj i sagitalnoj ravni, različite vrste skokova, među njima i skokove karakteristične za određenu sportsku granu (Nešić, 2008). Ove karakteristike zahtjevaju adekvatnu pripremljenost $\mathrm{i}$ visoke performanse u odnosu na sportsku tehniku, taktiku i bazičnu i specifičnu fizičku pripremu, s obzirom da postoji veliki broj skakačkih tehnika u zavisnosti od specifičnosti sportske grane (Zatsiorsky i Kraemer, 2006). Savremena odbojka pokazuje sve više i značajnije vezivanje za nauku, koja otvara nove puteve i nova gledanja na trening odbojkaša (Ivanović, Dopsaj, Nešić i Stanković, 2010). Obzirom da osnovni odbojkaški elementi uključuju i čitav niz motoričkih radnji kako bi njihovo izvođenje bilo pravilno, ujedno i efikasno, razumljivo je i potpuno opravdano očekivati da će trenažni rad na poboljšanju tih elemenata uticati i na razvoj 
motoričkih sposobnosti (Nešić, Sikimić, Ilić i Stojanović, 2011). Savremena odbojkaška igra zahtjeva od svih igrača visok nivo opštih motoričkih sposobnosti, kao i specifičnih - karakterističnih za odbojkašku igru i za određene igračke pozicije (Martinović i saradnici, 2011). Igrači moraju biti pripremljeni da perfektno izvedu svaki tehničko-taktički element. Fazi učenja, usvajanja ili perfektnog izvođenja ovih elemenata, mora se posvetiti maksimalna pažnja, kako bi se oni mogli izvesti pravilno, brzo, snažno i precizno. Poštujući postupnost i metodičnost u procesu obuke, neophodno je pronaći adekvatan „najkraći put“ od odbojkaša početnika do odbojkaša koji posjeduje čitav niz odbojkaških znanja i umjenja kojima može efikasno da manipuliše (Jurko, Nešić i Stojanović, 2013). Zato, faze obučavanja osnovnih elemenata odbojkaške tehnike, u mlađim takmičarskim kategorijama (kao i u školama odbojke), nikada neće prestati da budu primaran imperativ - neizostavan dio procesa „stvaranja“ kvalitetnog odbojkaša (Nešić, 2005)!

Cilj ove studije je prikaz i analiza uticaja odbojkaškog treninga na promjene nekih opštih i specifičnih motoričkih sposobnosti odbojkašica uzrasta 13-14 godina, odnosno da li će tromjesečni odbojkaški trening tehnike uticati na promjene posmatranih varijabli.

\section{METODE}

Uzorak ispitanika je predstavljalo 40 ispitanica, polaznica škole odbojke ”DIF“ iz Beograda. U ovom istraživanju uzorak varijabli je podijeljen u dva subuzorka (varijable za procjenu opštih motoričkih sposobnosti i varijable za procjenu specifičnih sposobnosti u odbojci). Prvog dana, izvršena su mjerenja tjelesne visine $i$ tjelesne mase i sprovedeni testovi: skok u dalj iz mjesta, dohvat u bloku, trčanje na $20 \mathrm{~m}$, a drugog dana sprovedena su preostala tri testa: Rassel-Langeov test - „odigravanje prstima”, Rassel-Langeov test „odigravanje čekićem“ $i$ Rassel-Langeov test - servis.

Inicijalno i finalno testiranje je sprovedeno baterijom testova na polaznicama škole odbojke "DIF", u razmaku od tri mjeseca - primjenom metode pre-test - post-test. Analizirani su rezultati dobijeni testiranjem određenih opštih i specifičnih motoričkih sposobnosti.

Kada se radi o eksperimentalnom faktoru koji je djelovao tokom tri mjeseca, važno je napomenuti da su se treninzi održavali 4 puta nedjeljno.

\section{Procedura testiranja i opis primjenjenih testova}

Dana 1. i 2. marta 2013. godine, u periodu od 10:00 do 13:00 časova, izvršeno je testiranje motoričkih sposobnosti polaznica škole odbojke „DIF“ - Beograd (u sali Fakulteta sporta i fizičkog vaspitanja u Beogradu). Testiranje je izvršeno pomoću baterije testova, sa pauzom između dva obavezna pokušaja u trajanju od 2 minuta (od kojih se bolji rezultat uzima kao konačan). Prvog dana, izvršena su mjerenja tjelesne visine $\mathrm{i}$ tjelesne mase i sprovedeni testovi: skok u dalj iz mjesta, dohvat u bloku, trčanje na $20 \mathrm{~m}$; a drugog dana sprovedena su preostala tri testa: Rassel-Langeov test - "odigravanje prstima", Rassel-Langeov test odigravanje "čekićem" i Rassel-Langeov test - servis.

Takođe, 1. i 2. juna iste godine, u periodu od 10:00 do 13:00, u sali Fakulteta sporta i fizičkog vaspitanja u Beogradu, ponovo su sprovedeni već pomenuti testovi, kako bi se utvrdilo da li je došlo, i u kojoj meri, do promjene nivoa opštih i specifičnih sposobnosti, nakon tri mjeseca treniranja.

Prije testiranja, ispitanicama su izmjerene tjelesna masa i tjelesna visina. Nakon toga je uslijedilo izvođenje aerobnih vježbi i vježbi oblikovanja umjerenog intenziteta - u cilju zagrijevanja u trajanju od 10 minuta. Ispitivanje je izvršeno baterijom testova:

Prvi dan

- Skok u dalj iz mjesta;

- Dohvat u bloku;

- Trčanje na $20 \mathrm{~m}$.

Drugi dan

- Rassel-Lange-ov test - odigravanje lopte "prstima" od zid;

- Rassel-Lange-ov test - odigravanje lopte "čekićem" od zid;

- Rassel-Lange-ov test - servis (broj ubačenih servisa).

Za mjerenja antropometrijskih karakteristika, korišćeni su sljedeći instrumenti:

- antropometar po Martinu i

- vaga koja omogućuje tačnost mjerenja od 0,5 kg i kod koje postoji mogućnost regulisanja kazaljke na nulti položaj.

Nakon što su izmjerene tjelesna visina i tjelesna masa, prvog dana sprovedena je i baterija testova:

\section{Skok $u$ dalj iz mjesta}

Instrumenti: Ravna, ali ne klizava površina sa obilježenim skakalištem, na kome je odskočište na istom nivou kao i doskočište.

Zadatak: Ispitanica se sunožno odrazi sa kraja odrazne linije i doskoči što može dalje. Obavezan je sunožni doskok. Izvode se dva skoka. Nepravilno izveden skok se ponavlja.

Ocjenjivanje: Kao tačka mjerenja uzima se tačka 
dodira pete sa površinom koja je najbliža liniji odskoka. Tačnost mjerenja je $1 \mathrm{~cm}$. U obzir se uzima najduži skok izmjeren u cm.

Napomene: Skok se izvodi iz sunožnog položaja. Dozvoljeno je podizanje na prste prije odraza (Ivanić, 1988).

\section{Dohvat u bloku}

Instrumenti: Odbojkaška mreža, visinometar.

Zadatak: Stav raskoračni u širini ramena, ruke u poziciji za blok, ispitanica vrši maksimalni sunožni skok, imitirajući rukama blokiranje lopte. Obavezan je sunožni doskok. Izvode se dva skoka.

Ocjenjivanje: Mjeri se visina dohvata. Tačnost mjerenja je $1 \mathrm{~cm}$. U obzir se uzima najviši skok izmjeren $\mathrm{u} \mathrm{cm}$.

Napomene: Skok se izvodi iz sunožnog položaja. Dozvoljeno je podizanje na prste prije odraza.

\section{Tréanje na $20 \mathrm{~m}$.}

Instrumenti: Pištaljka, štoperica, dva stalka za obilježavanje cilja.

Zadatak: Ispitanica stoji u položaju visokog starta iza startne linije. Komanda je samo "pozor!” i zvuk pištaljke. Ispitanica trči prema liniji cilja. Trče istovremeno dve ispitanice. Izvode se dva pokušaja, a računa se bolji.

Ocjenjivanje: Mjeri se vrijeme od zvuka pištaljke do trenutka kada ispitanica grudima pređe vertikalnu ravan koja se nalazi na liniji cilja. Mjerenje je u sekundama.

Napomene: Starter stoji u produžetku linije starta, a mjerilac 5-7 m u produžetku linije cilja. Ispitanicu treba upozoriti da trči punom brzinom kroz cilj.

Drugog dana, sprovode se preostala tri testa:

Rassel-Lange-ov volleyball test - odigravanje lopte "prstima" od zid

Instrumenti: Lopta, pištaljka, štoperica.

Zadatak: Ispitanica stoji na udaljenosti $1 \mathrm{~m} \mathrm{od}$ zida. $\mathrm{Na}$ visini od 2,28 $\mathrm{m}$ je povučena linija. $\mathrm{Na}$ dati znak baci loptu na zid, a zatim je prstima odbija preko obilježene linije bez zastoja. Zadatak je da se lopta odigrava što veći broj puta u vremenskom intervalu od 30 sekundi. Ako ispitanica izgubi kontrolu nad loptom, ponovo se vraća u početni položaj. Obilježena linija ispred zida ne smije se prelaziti. Ima pravo na dva pokušaja, bolji se boduje.

Ocjenjivanje: Ocjenjuje se broj izvedenih odigravanja.

Napomene: Mjerilac stoji sve vrijeme pored ispitanika i podstiče da izvede što veći broj odbijanja lopte od zid.
Rassel-Lange-ov volleyball test

- odigravanje lopte "cekicem" od zid

Instrumenti: Lopta, pištaljka, štoperica.

Zadatak: Ispitanica stane na $1 \mathrm{~m}$ od zida. $\mathrm{Na}$ visini od 2,28 m je povučena linija. $\mathrm{Na}$ dati znak baci loptu na zid, a zatim je čekićem odbija preko obilježene linije bez zastoja. Zadatak je da se lopta odigrava što veći broj puta u vremenskom intervalu od 30 sekundi. Ako ispitanica izgubi kontrolu nad loptom, ponovo se vraća na početni položaj. Obilježena linija ispred zida ne smij se prelaziti. Ima pravo na dva pokušaja, bolji se boduje.

Ocjenjivanje: Ocjenjuje se broj izvedenih odbijanja.

Napomene: Mjerilac stoji sve vrijeme pored ispitanika i podstiče da izvede što veći broj odbijanja lopte od zid.

\section{Rassel-Lange-ov volleyball test - servis (Slikea1)}

Instrumenti: Lopta, odbojkaška mreža, pištaljka. Zadatak: Test se sprovodi na odbojkaškom igralištu. Sa jedne polovine se servira, a druga je obilježena. Svaka ispitanica ima pravo na deset servisa i pokušava da postigne što više poena, tj. što više ubačenih servisa. Ima pravo na dva pokušaja, a bolji rezultat se boduje. Ocjenjivanje: Računa se broj ubačenih servisa.

Napomene: Servira se gornji servis.

\section{Eksperimentalni tretman}

Kada se radi o eksperimentalnom tretmanu, koji je djelovao tokom tri mjeseca, važno je napomenuti da su se treninzi održavali 4 puta nedjeljno i da su trajali 1h i 30min (Nešić, 2005). Treninzi su se održavali srijedom, petkom, subotom i nedjeljom. Kada su u pitanju sami treninzi, važno je napomenuti da je na njima uglavnom bilo aktuelno usavršavanje usvojenih tehničkih elemenata - kroz široki spektar različitih vježbi, kao i nastavak obučavanja novih elemenata odbojkaške igre. Na treninzima se dosta pažnje obraćalo na pravilno izvođenje odbojkaških elemenata tehnike, uz eventualnu korekciju grešaka. Kada su u pitanju usmjerene i specifične (situacione) vježbe, one su, u odnosu na gore navedene, imale malo manju zastupljenost - ali to ne znači da je ovaj važan dio treninga takmičarskog uzrasta bio znatno manje tretiran. Orijentacija škole odbojke "DIF" je da djecu ne bi trebalo uvoditi rano u specijalizaciju (Kenny i Gregory, 2006).

\section{Obrada podataka}

Podaci dobijeni tokom istraživanja, obrađeni su postupcima deskriptivne i komparativne statistike. Podaci su obrađeni pomoću programa SPSS 19.0.

Iz prostora komparativne statistike, korišćen je t-test za male zavisne uzorke - prilikom testiranja 


\section{SLIKA 1}

Rassel-Langeov volleyball test-servis.

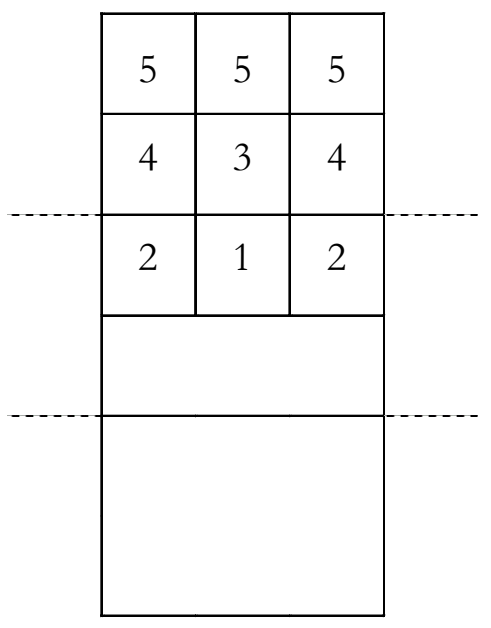

značajnosti između prosječnih rezultata dobijenih na inicijalnom i finalnom mjerenju za svaku varijablu (sve varijable iz antropomotoričkog prostora, kao i sve varijable iz morfološkog prostora).

\section{REZULTATI}

Na Tabeli 2 su prikazani osnovni deskriptivni pokazatelji testiranih djevojčica sa podacima o uzrastu i osnovnim morfološkim karakteristikama. Na osnovu rezultata se može vidjeti, da je prosječna visina ispitanica $161,15 \mathrm{~cm}$, prosječna tjelesna masa 49,63 kg, dok je prosječna vrijednost BMI 19,04 kg/ $\mathrm{cm}^{2}$.

$\mathrm{Na}$ Tabeli 3 su prikazani osnovni deskriptivni pokazatelji eksplozivnosti, brzine i preciznosti. Takođe su prikazane i najveće vrijednosti rezultata testova, minimalne vrijednosti, vrijednosti standardne devijacije, koeficijenta varijacije, kao i prosječne vrijednosti.

\section{TABELA 1}

Program treninga škole odbojke „DIF“-Beograd.

- Akrobatika, Tehnika odigravanja prstima naprijed, Tehnika odigravanja čekićem naprijed.

- Osnovni odbojkaški stavovi, Tehnika odigravanja prstima nazad, Tehnika odigravanja čekićem nazad.

- Škola trčanja, Tehnika donjeg servisa.

- Ples, Tehnika gornjeg servisa.

- Akrobatika, Tehnika odigravanja prstima iz kretanja, Tehnike odigravanja čekićem iz kretanja.

- Osnovni odbojkaški stavovi, Odigravanje prstima i čekićem u stranu.

- Škola bacanja loptice, Kombinacija prsti - čekić.

- Ples, *Igra 6:6 (upoznavanje sa pravilima igre i sistemom 6:0).

- Akrobatika, Tehnika odigravanja prstima napred, Tehnika odigravanja čekićem naprijed.

- Osnovni odbojkaški stavovi, Tehnika odigravanja prstima nazad, Tehnika odigravanja čekićem nazad.

- Škola trčanja, Tehnika donjeg servisa.

- Ples, Tehnika gornjeg servisa.

- Akrobatika, Tehnika odigravanja prstima iz kretanja, Tehnike odigravanja čekićem iz kretanja.

- Osnovni odbojkaški stavovi, Odigravanje prstima i čekićem u stranu.

- Škola bacanja loptice, Kombinacija prsti - čekić.

- Ples, *Igra 6:6 (upoznavanje sa pravilima igre i sistemom 6:0).

- Osnovni odbojkaški stavovi, Prijem donjeg servisa čekićem.

- Škola bacanja loptice, *Igra 6:6 (upoznavanje sa pravilima igre i sistemom 6:0).

- Ples, Smečiranje sa podbacivanjem od strane trenera (zona 4, 3, 2).

- Akrobatika, Tehnika smečiranja - trener pridržava loptu (zona 4, 3, 2).

- Stavovi i položaji, Tehnika gornjeg servisa.

- Škola trčanja, Ponavljanje i utvrđivanje svih naučenih elementa tehnike. 
- Ples, Razmještanje igrača na terenu sistem igre 6:0.

- Akrobatika, Tehnika gornjeg servisa.

- Osnovni odbojkaški stavovi, Prijem donjeg servisa čekićem.

- Škola bacanja loptice, *Igra 6:6 (upoznavanje sa pravilima igre i sistemom 6:0).

- Ples, Smečiranje sa podbacivanjem od strane trenera (zona 4, 3, 2).

- Akrobatika, *Igra 6:6 (donji i gornji servis, prijem čekićem, dizanje lopte i napad prstima).

- Stavovi i položaji, Smečiranje sa podbacivanjem od strane trenera (zona 4).

- Škola trčanja, Tehnika individualnog bloka - dokorak.

- Ples, Prijem donjeg i gornjeg servisa čekićem.

- Akrobatika, Tehnika individualnog bloka - prekorak.

- Osnovni odbojkaški stavovi, Prijem donjeg i gornjeg servisa prstima.

- Škola bacanja loptice, *Igra 6:6 (donji i gornji servis, prijem čekićem, dizanje lopte i napad smečiranjem).

- Ples, Smečiranje sa podbacivanjem lopte od strane trenera iz zone 4, 3, 2.

Maj - Akrobatika, Odbrana čekićem.

- Osnovni odbojkaški stavovi, Tehnika individualnog bloka - dokorak i prekorak.

- Škola trčanja, *Igra 6:6 (gornji servis, prijem čekićem, dizanje lopte i napad smečiranjem).

- Ples, Gornji servis sa zadatkom (paralela i dijagonala).

- Akrobatika, Smečiranje sa zadatkom (paralela i dijagonala).

- Stavovi i položaji, *Igra 6:6 (gornji servis, prijem čekićem, dizanje lopte i napad smečiranjem).

- Škola bacanja loptice, Tehnika dvojnog bloka - kretanje.

- Ples, *Igra 6:6 (gornji servis, prijem čekićem, dizanje lopte i napad smečiranjem).

\begin{tabular}{|c|c|}
\hline & Finalno mjerenje: \\
\hline Tut & $\begin{array}{l}\text { - antropometrijske karakteristike } \\
\text { - motorne sposobnosti }\end{array}$ \\
\hline
\end{tabular}

$\mathrm{Na}$ Tabeli 4. su prikazani rezultati osnovnih deskriptivnih pokazatelja testiranih ispitanica, sa podacima o uzrastu i osnovnim morfološkim karakteristikama. Na osnovu dobijenih rezultata mjerenja može se utvrditi da nije došlo do značajnijih pomaka u smislu tjelesne visine, tjelesne mase i BMI. Naravno, ova činjenica nije uslovljena eksperimentom, već je to efekat faktora rasta.

$\mathrm{Na}$ Tabeli 5. su prikazani i osnovni deskriptivni pokazatelji eksplozivnosti, brzine i preciznosti. Takođe su prikazane i najveće vrijednosti rezultata testova, minimalne vrijednosti, vrijednosti standardne devijacije, kao i prosječne vrijednosti.

\section{DISKUSIJA}

$\mathrm{Na}$ osnovu dobijenih rezultata može se zaključiti da kod tjelesne visine, tjelesne mase i BMI-a, nije došlo do značajnih promjena (mada je evidentno minimalno povećanje prosječne vrijednosti tjelesne visine, kao i smanjenje prosječne vrijednosti tjelesne mase i BMI-a). Međutim, kod opštih i specifičnih motoričkih sposobnosti je uočljivo poboljšanje (u različitom stepenu) nakon 3 meseca odbojkaškog treninga.

Kada je u pitanju opšta motorika, najslabije poboljšanje je utvrđeno kod testa „trčanje na 20 m“. Ovo je i logično, jer je brzina motorička sposobnost koja se veoma teško može poboljšati, pogotovo u uzrastu od 13-14 godina - kada se prirodni prirast brzine privodi kraju (Cole, Bellizzi, Flegal i Dietz, 2000). Statistički značajno poboljšanje rezultata je utvrđeno kod testa ,skok u dalj iz mjesta“. Kada je u pitanju test „dohvat u bloku“, takođe je utvrđeno poboljšanje rezultata u post-testu - ali je poboljšanje manje izraženo (što može da se objasni time što, u metodici obučavanja odbojkaške tehnike, nema mnogo vježbi koje insistiraju na maksimalnom angažovanju vertikalne komponente brzinske snage i eksplozivnosti opružača nogu - što bi značilo da nema mnogo vertikalnih odskoka - što iz mjesta, što iz kretanja.

$S$ druge strane, kada se radi o specifičnim motoričkim sposobnostima, može se uočiti da je, u post-testu, došlo do poboljšanja rezultata - i to u značajnijim okvirima nego kod rezultata opštih motoričkih sposobnosti, odnosno tromjesečni odbojkaški trening tehnike je uticao na promjene posmatranih varijabli, a statistička značajnost je utvrđena kod testova specifičnih motoričkih sposobnosti, kao i kod testa skok u dalj iz mjesta.

Rezultati pokazuju da je primjenjeni model odbojkaškog treninga dominantno uticao na specifičnu motoriku, u odnosu na opštu. Dobijeni rezultati govore u prilog uticaja primjenjenog modela odbojkaškog treninga na edukativnu komponentu, nasuprot razvojne sa aspekta fizičkih sposobnosti, što se poklapa sa postojećom teorijom metodike obučavanja. Promjene do kojih je došlo u ispoljavanju specifične motorike su rezultat programa trenažnog procesa u tri mjeseca 


\section{TABELA 2}

Rezultati inicijalnog mjerenja osnounih deskriptivnih pokazatelja testiranih ispitanica, sa podacima o uzrastu i osnounim morfološkim karakteristikama.

\begin{tabular}{lrrrrrr}
\hline & $N$ & \multicolumn{1}{c}{ Min } & \multicolumn{1}{c}{ Max } & \multicolumn{1}{c}{$M$} & \multicolumn{1}{c}{$S D$} & \multicolumn{1}{c}{$c$ \% } \\
\hline A & 40 & 13,00 & 14,00 & 13,500 & 0,513 & 3,80 \\
\hline BH & 40 & 144,00 & 175,00 & 161,150 & 8,833 & 5,48 \\
\hline BM & 40 & 33,00 & 65,00 & 49,625 & 8,547 & 17,22 \\
\hline BMI & 40 & 15,07 & 24,14 & 19,040 & 2,292 & 12,04 \\
\hline
\end{tabular}

Legenda: A - Uzrast; BH - Visina tijela; BM - Težina tijela; BMI - Body Mass Index;

$N$ - Ukupan broj ispitanika; Min - Minimum; Max - Makimium; $M$ - Aritmetička sredina; $S D$ - Standardna devijacija; $c V \%$ - \% koeficijent varijacije.

TABELA 3

Requltati inicijalnog testiranja ispitanica - podaci o procenjenim motorickim varijablama.

\begin{tabular}{lcrrrrr}
\hline & $N$ & \multicolumn{1}{c}{ Min } & Max & \multicolumn{1}{c}{$M$} & \multicolumn{1}{c}{$S D$} & \multicolumn{1}{c}{$c{ }^{\%}$} \\
\hline SLJ & 40 & 160,00 & 190,00 & 176,750 & 8,472 & 4,79 \\
\hline BR & 40 & 210,00 & 240,00 & 226,250 & 7,412 & 3,27 \\
\hline 20R & 40 & 4,00 & 5,00 & 4,530 & 0,289 & 6,37 \\
\hline RLOP & 40 & 22,00 & 30,00 & 27,050 & 2,724 & 10,07 \\
\hline RLUP & 40 & 19,00 & 28,00 & 23,750 & 3,059 & 12,88 \\
\hline RLS & 40 & 7,00 & 10,00 & 8,250 & 0,967 & 11,72 \\
\hline
\end{tabular}

Legenda: SLJ - Skok u dalj iz mjesta; BR - Dohvat u bloku; 20R - Trčanje na 20 m;

RLOP - Rassel-Langeov test odigravanja lopte "prstima" od zid; RLUP - Rassel-Langeov test odigravanja lopte "čekićem” od zid; RLUP - Rassel-Langeov test servisa - broj ubačenih servisa; $N$ - Ukupan broj ispitanika; Min - Minimum; Max - Makimium; $M$ - Aritmetička sredina; $S D$ - Standardna devijacija; $c V \%$ - \% koeficijent varijacije.

\section{TABELA 4}

Rezultati osnounih deskriptivnih pokazatelja finalnog mjerenja testiranih ispitanica, sa podacima o uzrastu i osnovnim morfološkim karakteristikama.

\begin{tabular}{lrrrrrr}
\hline & $N$ & \multicolumn{1}{c}{ Min } & \multicolumn{1}{c}{$\operatorname{Max}$} & \multicolumn{1}{c}{$M$} & \multicolumn{1}{c}{$S D$} & \multicolumn{1}{c}{$c$ \% } \\
\hline A1 & 40 & 13,00 & 14,00 & 13,500 & 0,513 & 3,79 \\
\hline BH1 & 40 & 145,00 & 176,00 & 161,950 & 8,982 & 5,54 \\
\hline BM1 & 40 & 33,00 & 64,00 & 48,800 & 8,340 & 17,09 \\
\hline BMI1 & 40 & 14,86 & 23,57 & 18,527 & 2,219 & 11,97 \\
\hline
\end{tabular}

Legenda: A - Uzrast; BH - Visina tijela; BM - Težina tijela; BMI - Body Mass Index;

$N$ - Ukupan broj ispitanika; Min - Minimum; Max - Makimium; $M$ - Aritmetička sredina; $S D$ - Standardna devijacija; $c V \%$ - \% koeficijent varijacije.

treninga, koji je sproveden na ispitanicima. Naime, program treninga je bio posvećen samo tehnici, odnosno specifičnoj motorici, te je stoga moralo da dođe do pomenutih razlika (Nešić, 2002). S druge strane, od testiranih opštih motoričkih sposobnosti, jedino je kod skoka u dalj došlo do značajnije razlike
- što se može komentarisati kao produkt kretanja i lokomocija prilikom treniranja specifičnih motoričkih sposobnosti (Janković i Marelić, 1995). Kretanja i lokomocije koje se manifestuju tom prilikom su u horizontalnoj ravni, odnosno prisutne su nagle promjene pravca i smjera kretanja (istrčavanja naprijed - nazad, 


\section{TABELA 5}

Rezultati finalnog testiranja ispitanica - podaci o procenjenim motoričkim varijablama.

\begin{tabular}{lrrrrrr}
\hline & $N$ & \multicolumn{1}{c}{ Min } & \multicolumn{1}{c}{$\operatorname{Max}$} & \multicolumn{1}{c}{$M$} & \multicolumn{1}{c}{$S D$} & $c V \%$ \\
\hline SLJ1 & 40 & 170,00 & 200,00 & 184,750 & 8,347 & 4,52 \\
\hline BR1 & 40 & 210,00 & 245,00 & 229,750 & 8,347 & 3,63 \\
\hline 20R1 & 40 & 4,00 & 4,90 & 4,450 & 0,265 & 5,49 \\
\hline RLOP1 & 40 & 25,00 & 33,00 & 28,600 & 1,903 & 6,65 \\
\hline RLUP1 & 40 & 22,00 & 30,00 & 26,350 & 2,159 & 8,19 \\
\hline RLS1 & 40 & 7,00 & 10,00 & 8,850 & 0,813 & 9,18 \\
\hline
\end{tabular}

Legenda: SLJ - Skok u dalj iz mjesta; BR - Dohvat u bloku; 20R - Trčanje na 20 m;

RLOP - Rassel-Langeov test odigravanja lopte "prstima" od zid; RLUP - Rassel-Langeov test odigravanja lopte "čekićem" od zid; RLUP - Rassel-Langeov test servisa - broj ubačenih servisa; $N$ - Ukupan broj ispitanika; Min - Minimum; Max - Makimium; $M$ - Aritmetička sredina; $S D$ - Standardna devijacija; $c V \%$ - \% koeficijent varijacije.

\section{TABELA 6}

Rezultati statističke raqlike (statistička značajnost) testiranib ispitanica u odnosu na inicijalno i finalno mjerenje i procjenjivanje morfoloških i motoričkih karakteristika i sposobnosti (t-test za male zavisne uzorke).

\begin{tabular}{lccc}
\hline & $t$ & $d f$ & $p$ \\
\hline Pair 1 & 0,498 & 39 & 0,620 \\
\hline Pair 2 & 0,190 & 39 & 0,850 \\
\hline Pair 3 & 1,050 & 39 & 0,300 \\
\hline Pair 4 & $-13,597$ & 39 & $\mathbf{0 , 0 0 0}$ \\
\hline Pair 5 & $-1,398$ & 39 & 0,170 \\
\hline Pair 6 & 0,589 & 39 & 0,560 \\
\hline Pair 7 & $-2,121$ & 39 & $\mathbf{0 , 0 4 0}$ \\
\hline Pair 8 & $-9,313$ & 39 & $\mathbf{0 , 0 0 0}$ \\
\hline Pair 9 & $-2,130$ & 39 & $\mathbf{0 , 0 4 0}$ \\
\hline
\end{tabular}

Legenda: Pair 1 - Visina tijela - Visina tijela 1; Pair 2 - Masa tijela - Masa tijela 1;

Pair 3 - BMI - BMI 1; Pair 4 - Skok u dalj iz mjesta - Skok u dalj iz mjesta 1;

Pair 5 - Dohvat u bloku - Dohvat u bloku 1; Pair 6 - Trčanje na 20 m - Trčanje na 20 m 1; Pair 7 - Rassel-Langeov test odigravanja lopte "prstima" od zid - Rassel-Langeov test odigravanja lopte "prstima" od zid 1; Pair 8 - Rassel-Langeov test odigravanja lopte "čekićem" od zid - Rassel-Langeov test odigravanja lopte "čekićem" od zid 1;

Pair 9 - Rassel-Langeov test servisa, broj ubačenih servisa - Rassel-Langeov test servisa, broj ubačenih servisa $1 ; t$ - Studentova distribucija; $d f$ - Stepeni slobode; $p$ - Vjerovatnoća.

u stranu...), što odgovara ispoljavanju agilnosti, a što svakako doprinosi razvoju eksplozivnosti opružača nogu - kada je u pitanju horizontalna komponenta, što je važno za rezultat u skoku u dalj iz mesta, u ovom slučaju (Dopsaj, 1994; Milišić, 2003).

Rezultati su pokazali da je, poslije tri mjeseca primjene odbojkaškog treninga, došlo do određenog poboljšanja opštih i specifičnih antropomotoričkih sposobnosti koje su testirane. Naravno, treba uzeti u obzir da nije postojala mogućnost formiranja kontrolne grupe, te iz tog razloga postoji mogućnost određene greške u dobijenim rezultatima. U pogledu tjelesne visine i tjelesne mase, nije došlo do statistički značajnih promjena u ovom periodu, te se može reći da je ta greška zanemarljiva (što znači da efekat maturacije, kao mjera unutrašnje valjanosti statističkog zaključivanja, nije značajno izražen). 


\section{ZAKLJUČAK}

U ovom istraživanju, bio je aktuelan pre-test post-test eksperimentalni nacrt istraživanja, ali bez kontrolne grupe. Rezultati su pokazali da je, poslije tri mjeseca primjene odbojkaškog treninga, došlo do određenog poboljšanja opštih i specifičnih motoričkih sposobnosti koje su testirane. Takođe, rezultati su pokazali da je primjenjeni model odbojkaškog treninga dominantno uticao na specifičnu motoriku, u odnosu na opštu. Predselekcija i selekcija imaju svoj puni smisao jedino kada se ne oslanjaju samo na procjenu aktuelnih osobina i sposobnosti, već se posmatraju i vrednuju u sklopu sa prognoziranjem prirasta, koji treba da donese proces sportske obuke (Stojanović, Kostić i Nešić, 2005, 2010).

Testiranje motoričkih sposobnosti je samo pomoćna informacija, koja nikako ne daje uvid o cjelokupnom stanju treniranosti, jer je trening mnogo kompleksniji proces usavršavanja - ne samo fizičke sposobnosti, već i njenog maksimalnog ispoljavanja u konkretnim uslovima takmičenja (Zatsiorsky i Kraemer, 1995).

\section{ZAHVALNOST}

Rad je dio Projekta „Efekti primenjene fizičke aktivnosti na lokomotorni, metabolički, psiho-socijalni i vaspitni status populacije Republike Srbije" pod brojem III47015, a kao dio potprojekta "Efekti primenjene fizičke aktivnosti na lokomotorni, metabolički, psiho-socijalni i vaspitni status populacije sportista Republike Srbije" koji se finansira od strane Ministarstva prosvjete, nauke i tehnološkog razvoja Republike Srbije - Ciklus naučnih projekata 2011-2014.

\section{LITERATURA}

Bompa, T. (2005). Cjelokupan trening za mlade pobjednike [Total training for young champions]. Zagreb, HR: Gopal.

Cole, T., Bellizzi, M., Flegal, K., \& Dietz, W. (2000). Establishing a standard definition for child overweight and obesity worldwide: international survey. MBJ, 320(7244), 1240-1243.

Dopsaj, M. (1994). Metode podizanja i održavanja sportske forme kod vrbunskib sportista u sportskim igrama [Methods of raising and maintaining the sports form in elite athletes in sports games]. Belgrade, RS: Jugoslovenski zavod za fizičku kulturu i medicinu sporta.

Ivanić, S. (1988). Kriterijumi za procenu fizičkog razvoja i fizičkih sposobnosti dece i omladine urrasta od $7-19$ godina (normativi) [Criteria for evaluation of physical development and physical abilities of children and adolescents aged $7-19$ years (norms)]. Belgrade, RS: Gradska samoupravna interesna zajednica fizičke kulture Beograda.

Ivanović, J., Dopsaj, M., Nešić, G., \& Stanković, R. (2010). Polni dimorfizam kod različitih indikatora za procenu izometrijske eksplozivne sile opružača nogu [Sexual dimorphism in various indicators for assessing explosive isometric knee extensor force]. Fizickea kultura, 64(1), 46-61.

Janković, V., \& Marelić, N. (1995). Odbojka [Volleyball]. Zagreb, HR: Fakultet fizičke kulture.

Jurko, D., Nešić, G., \& Stojanović, T. (2013). Does precompetitive anxiety affect perceived competitive efficacy of volleyball players? Facta Universitatis Series: Physical Education and Sport, 11(1), 57-64.

Kenny, B., \& Gregory, S. (2006). Volleyball- steps to success. Champaign, IL: Human Kinetics.

Martinović, J., Dopsaj, V., Kotur-Stevuljević, J., Dopsaj, M., Vujović, A., Stefanović, A., \& Nešić G. (2011). Oxidative stress biomarker monitoring in elite women volleyball athletes during a 6-week training period. J Strength Cond Res, 25(5), 1360-1367. doi: 10.1519/ JSC.0b013e3181d85a7f; PMid: 21157395

Milišić, B. (2003). Upravljanje treningom [Management of training]. Belgrade, RS: Autor.

Nešić, G. (2002). Osnovi antropomotorike

[Fundamentals of anthropomotorics]. Belgrade, RS: Sportska akademija.

Nešić, G. (2005). Model rada odbojkaške škole [Operating model of volleyball school]. Sportska medicina, 5(3), 136-145.

Nešić. G. (2008). Struktura takmičarske aktivnosti odbojkašica [Structure of competitive activity in female volleyball players]. In L. Radisavljević and L. Moskovljević (Eds.), Godišnjak No 14 (pp. 89-111). Belgrade, RS: Fakultet sporta i fizičkog vaspitanja.

Nešić, G. Sikimić, M., Ilić, V., \& Stojanović, T. (2011). Play structure of top female volleyball players: explorative factorial approach. $\mathrm{BrJ}$ Sports Med, 45, 541. doi: 10.1136/ bjsm.2011.084558.24

Stojanović, T., Kostić, R., \& Nešić, G. (2005). Odbojka [Volleyball]. Banja Luka, BA: Fakultet fizičkog vaspitanja i sporta.

Stojanović, T., Kostić, R., \& Nešić, G. (2010). Odbojka - tebnika i taktika [Volleyball - technique and tactics]. Banja Luka, BA: Fakultet fizičkog vaspitanja i sporta. 
Zatsiorsky, B. M., \& Kraemer, W. J. (1995). Science and practice of strength training. Champaign,
IL: Human kinetics. PMid: 7595983

Primljeno: 1. novembar, 2013 Izmjene primljene: 5. decembra, 2013

Prihvaćeno: 13 decembar, 2013

Korespodencija: Dr Goran Nešić

Fakultet sporta i fizičkog vaspitanja

Blagoja Parovića 156 11030 Beograd Srbija

Telefon: 00381641136305

E-mail: goran.nesic@fsfv.bg.ac.rs 